Journal of Sedimentary Petrology, Vol. 10, No. 3, PP. 142-145, Figs. 1-5, December, 1940

\title{
GAS PITS IN NON-MARINE SEDIMENTS
}

\author{
JOHN H. MAXSON \\ California Institute of Technology, Pasadena California
}

\section{ABSTRACT}

The generation of the natural gas methane during the decomposition of organic debris is responsible for minor phenomena of sedimentation termed gas pits. Some of these are small circular pits with surrounding mud mounds formed by the escape of gas bubbles from the surface of mud bars. Larger crater-like pits are formed in submerged mud and silt bars as the result of erosion in the vicinity of active gas bubble agitation.

Numerous small mud bars were observed in headwaters of Lake Mead in November, 1937, at the conclusion of a boat trip down the Colorado River through the Grand Canyon. These bars marked the early encroachment of river mud on the great lake impounded by Boulder Dam. In addition to the features so commonly found near shorelines, such as ripple mark, mud cracks, rain drop impressions, rill marks, bird and insect tracks, small deep pits were observed in numerous places. In some cases, as shown in figure 1, these pits were the centers of concentric lines of disturbance or accretion. The small pits were formed after emergence of the mud bar as shown by their replacement of raindrop impressions.

Field studies in the headwaters of Lake Mead in November, 1939, disclosed more extensive silt bars, especially across the

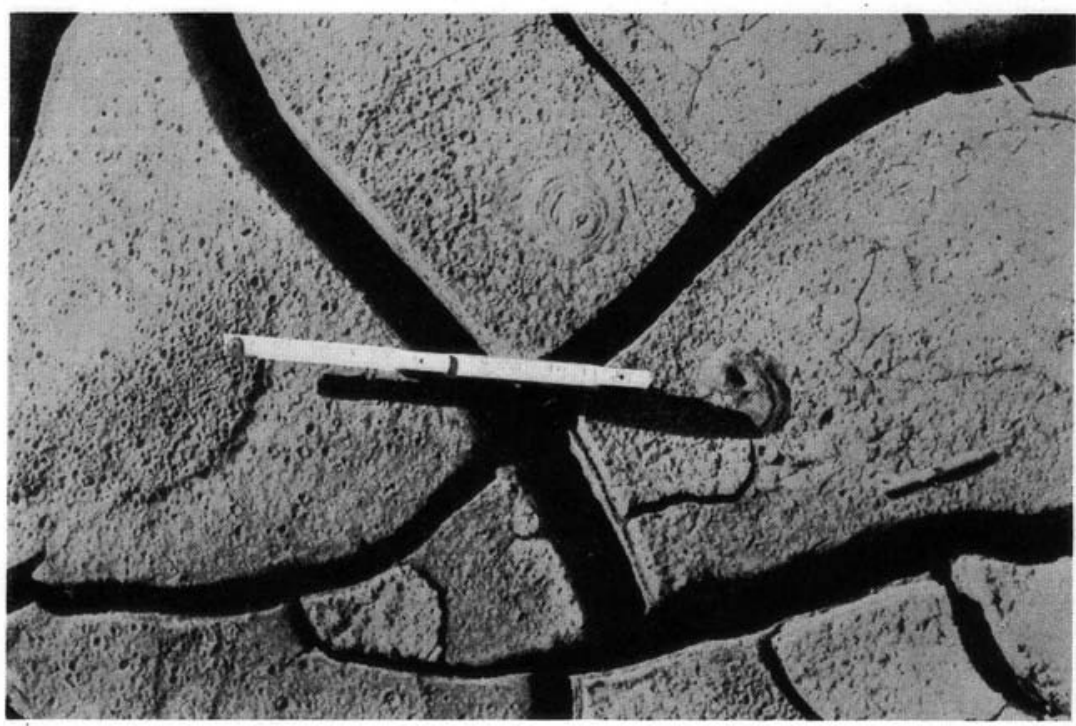

FIG. 1.-Small gas pits on mud bar at Reference Point no. 2, November, 1937. Note that the raindrop impressions were formed before the gas pits ceased activity. 


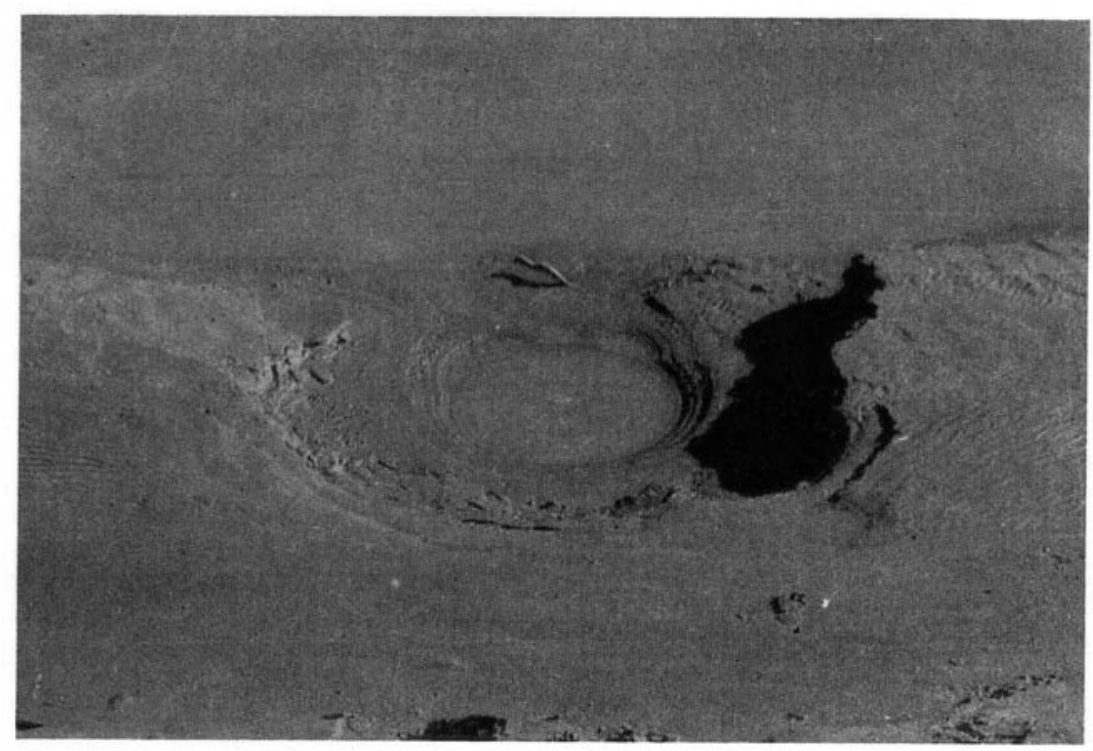

FIG. 2.-Partially emerged gas pit showing formation of strand lines by bubble-formed wavelets. The pool is about 18 inches in diameter.

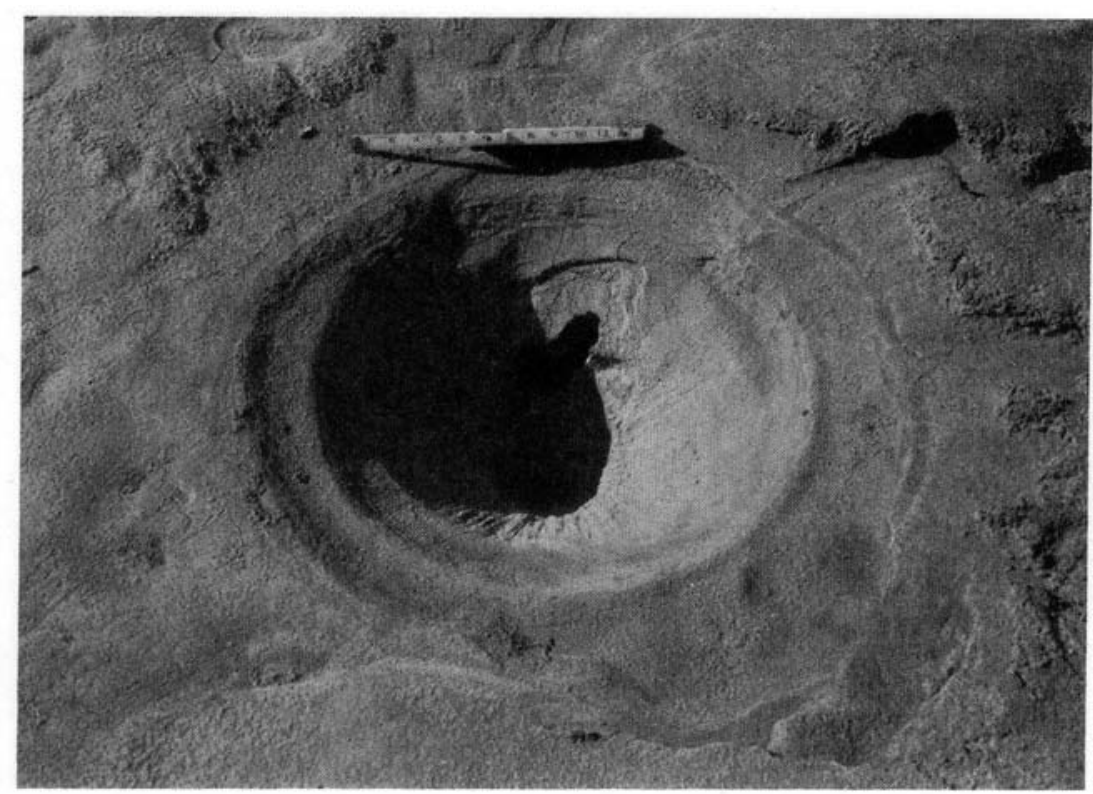

Fig. 3.-Typical steep-walled conical gas pit on mud bar at Lost Creek, November, 1939. 
drowned mouths of small tributaries to the Colorado River. The head of the lake in December, 1939, was at Separation Rapids and the turbidity extended to below Waterfall Canyon some 20 miles downstream. Over a large part of this area of deposition vigorous bubbling was taking place. The escaping gas was determined to be inflammable. An inlet cut through the baymouth mud bar of Lost Creek revealed a layer of odoriferous, black, decaying vegetal matter. Decomposition of such material by bacteria is known to yield methane, nitrogen, and carbon dioxide.

The larger pits found on the mud bars are believed to have formed under water as the result of erosive action engendered by bubble agitation. The process of pit formation is probably not merely nondeposition because the organic material is buried and during the time required for large scale bacterial action to be initiated considerable compaction of the sediment would take place. Non-deposition may, however, be important in maintaining small initial gas conduits through the mud which are later increased with larger volumes of gas. When partially exposed through lowering of the water level, the bubbles form concentric waves which attack the margins of the pits forming miniature beaches, strand lines, and sometimes little cliffs. Such a gas pit is illustrated in figure 2. In some cases the gas conduits remain open after the complete withdrawal of the water. An excellent example of a symmetrical gas pit is shown in figure 3 . Larger pits are formed when several gas conduits are adjacent as illustrated by figure 4 . If the water is withdrawn uniformly, a pit tends to possess a symmetrical inverted conical shape. If the water stands in the pit, the upper part of the cone may be broadened by the miniature wave attack.

Gas pits vary greatly in size. Some were observed having a diameter of a

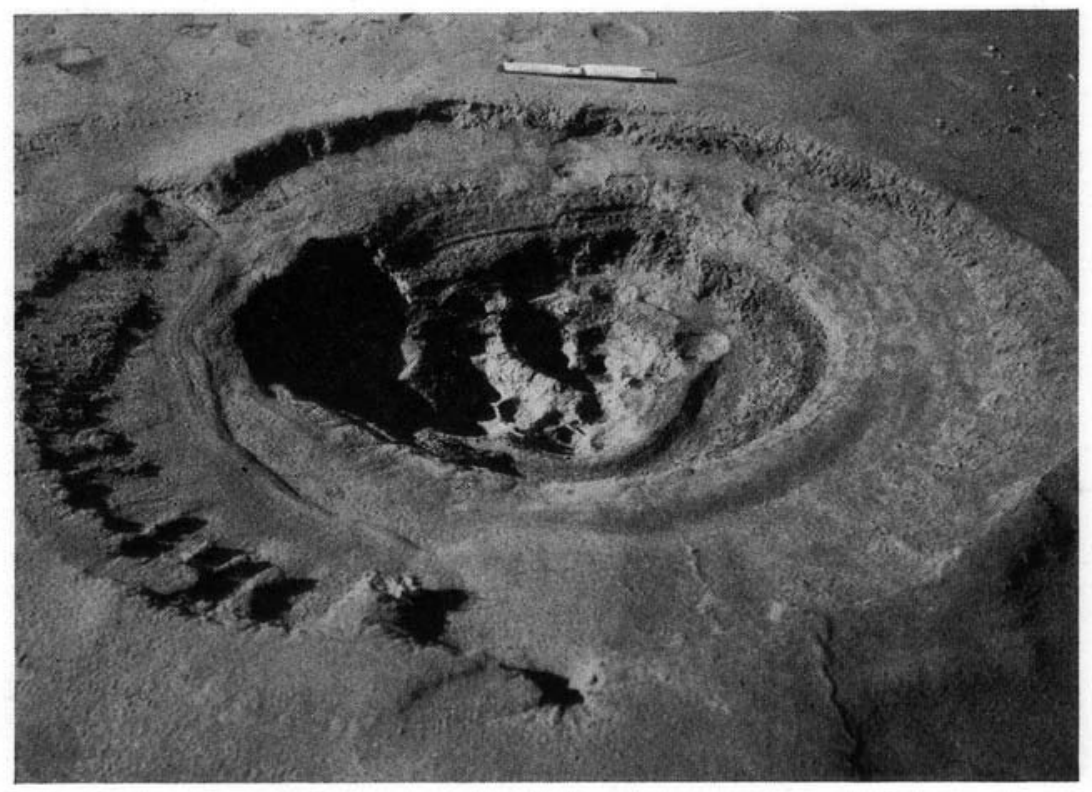

FIG. 4.- - Large emerged gas pit with multiple vents showing well developed strand line features in the upper part as the result of long continued stand of water at that level. 


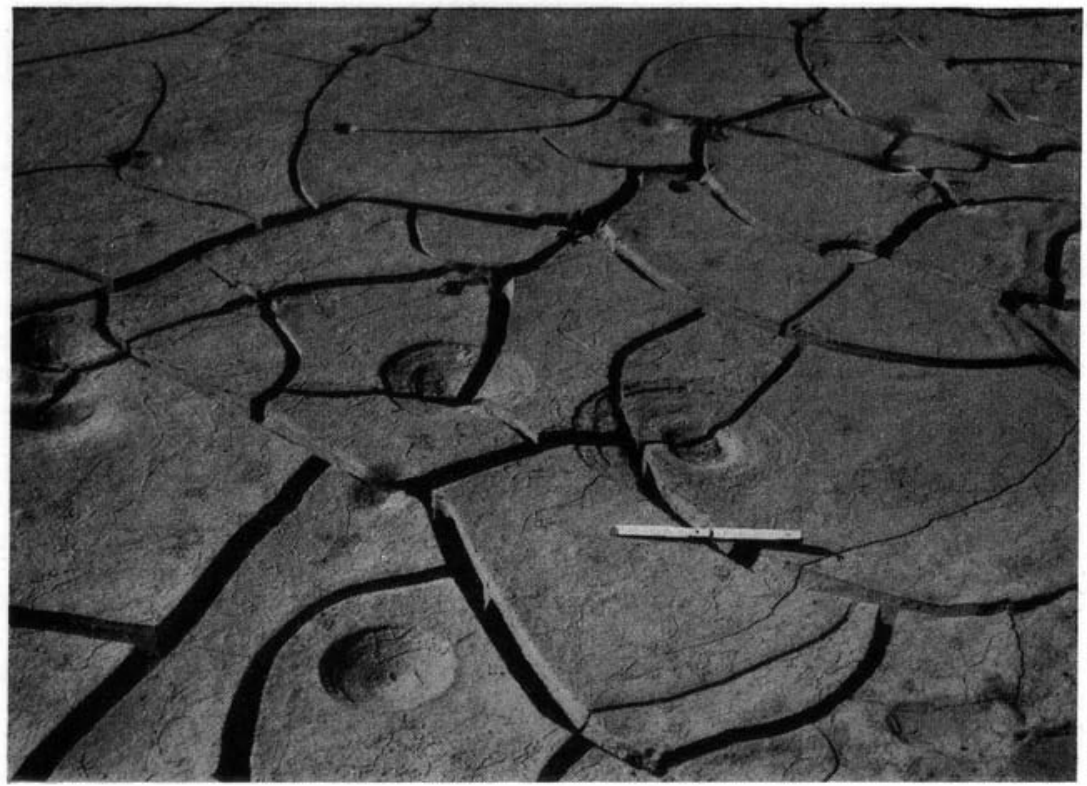

FIG. 5.-Gas pits in mud bar in various stages of obliteration. Lost Creek, November, 1939.

fraction of an inch; the largest had a diameter of 6 feet and a depth of 4 feet. The average size noted was about 1.5 feet in diameter and 8 inches in depth.

Gas pits are not enduring features and after emergence may be expected to be rapidly destroyed by rain wash. In later stages of filling the shallow concavity could only be recognized as a gas pit if intermediate stages were present. Figure 5 illustrates a number of hollows doubtless originating as gas pits. If similar hollows are found in lithified sediments it may be suspected that they originated in shallow water where sediment rich in organic debris was being deposited. However, they do not necessarily indicate deposition in an environment of humidity because the organic materials may have been transported to an arid region, such as the lower Grand Canyon in the case described.

Gas pits differ from mud volcanoes which are developed by mud deposits about gas vents on the earth's surface inasmuch as they are usually smaller and predominantly excavations. They are associated with the lower gas pressures of bacterially generated marsh gas rather than with the higher pressures of oilfield or volcanic gases.

Spring pits have been described (Quirke, 1930) on the shores of Maple Lake near Parry Sound, Ontario. These were formed in a sandy submerged beach by numerous water outlets. They were observed to be usually under 2 feet in diameter and 6 inches in depth. They appear to be more shallow and irregular than gas pits.

\section{ACKNOWLEDGEMENTS}

The writer wishes to thank Mr. E. D. McKee, who was a member of the 1937 Colorado River expedition, for criticism of the manuscript.

\section{REFERENCE}

Quirke, T. T., 1930, Spring pits, sedimentation phenomena: Jour. Geology, vol. 38, pp. 88-91 